\title{
A model for the formation of the Pradol (Pradolino) dry valley in W Slovenia and NE Italy
}

\author{
Model nastanka suhe doline Pradol (zahodna Slovenija, severovzhodna Italija)
}

Manuel DIERCKS ${ }^{1}$, Christoph GRÜTZNER ${ }^{2}$, Marko VRABEC ${ }^{3} \&$ Kamil USTASZEWSKI $^{2}$

${ }^{1}$ Institute for Geology, TU Bergakademie Freiberg, 09599 Freiberg, Germany

${ }^{2}$ Institute of Geological Sciences, Friedrich Schiller University Jena, 07749 Jena, Germany; e-mail: christoph.gruetzner@uni-jena.de

${ }^{3}$ University of Ljubljana, Faculty of Natural Sciences and Engineering, Department of Geology, Aškerčeva 12 SI-1000 Ljubljana, Slovenia

Prejeto / Received 27. 9. 2020; Sprejeto / Accepted 1. 7. 2021; Objavljeno na spletu / Published online 19. 7. 2021

Key words: wind gap, LGM, erosion, bedrock incision, Pradol

Ključne besede: suha dolina, zadnji glacialni maksimum, erozija, vrezovanje, Pradol

\begin{abstract}
In tectonically active mountain ranges, the landscape is shaped by the interplay of erosion/sedimentation and tectonically driven crustal deformation. Characteristic landforms such as moraines, wind gaps, fault scarps, and river terraces can be used to decipher the landscape evolution. However, the available data often allow for different interpretations. Here we study the Pradol (Pradolino) Valley in Western Slovenia, a deeply incised canyon whose floor rests several hundreds of metres above the surrounding valleys. We use high-resolution digital elevation models, geomorphic indices and field observations to unravel the evolution of this peculiar landform. We present a six-stage evolution model of the canyon that includes the blockage of valleys by advancing glaciers, river diversion, and rapid incision due to a high discharge of post-glacial meltwater. The formation of the Pradol Valley was most likely facilitated by an underlying fault that serves as an easily erodible weakness zone in the Mesozoic limestones. Our model indicates that the formation of the canyon could have occurred during the last glaciation, which results in incision rates of several $\mathrm{cm} / \mathrm{yr}$. With the proposed model we can explain all remote and field observations available. Our study shows that a complex interplay of different landscape-shaping processes is needed to explain the occurrence of the Pradol dry valley and that rapid changes in the morphology occurred after the last glacial maximum.
\end{abstract}

\section{Izvleček}

V tektonsko aktivnih gorovjih površje oblikujejo interakcije med erozijo, sedimentacijo in tektonsko gnanimi deformacijami skorje. Časovni razvoj oblikovanosti površja lahko rekonstruiramo s študijem značilnih površinskih oblik kot so morene, suhe doline, prelomni robovi in rečne terase, vendar pa so razpoložljivi podatki pogosto dvoumni in dopuščajo različne interpretacije. V prispevku obravnavamo globoko vrezano sotesko Pradol (Pradolina) v zahodni Sloveniji, katere dno leži nekaj sto metrov nad okoliškimi dolinami. Da bi ugotovili nastanek te nenavade geomorfne oblike smo uporabili visokoločljive digitalne modele višin, geomorfne indekse in terenska opazovanja. V prispevku predstavljamo šestfazni razvoj soteske, ki vključuje zajezitev doline z napredujočim ledenikom, preusmeritev reke in njeno hitro vrezovanje zaradi velike količine vode ob postglacialnem taljenju ledu. Nastanek Pradola je bil najverjetneje pogojen s prisotnostjo preloma, katerega prelomna cona je predstavljala lahko erodibilno cono šibkosti v mezozojskih apnencih. Naš model kaže, da bi soteska lahko v celoti nastala v zadnji poledenitvi, kar bi pomenilo hitrosti vrezovanja do nekaj cm na leto. Predlagani model pojasni vsa dostopna daljinska in terenska opažanja. Študija nakazuje, da je nastanek Pradola posledica kompleksnih interakcij različnih geomorfnih procesov, ter da je v obdobju od zadnje poledenitve prišlo do hitrih sprememb v morfologiji površja. 


\section{Introduction}

The Pradol Valley (also called Predol, Italian: Valle di Pradolino. In the following we only use the Slovenian names) is a wind gap located close to the village of Logje at the Slovenian-Italian border, approximately $12 \mathrm{~km}$ west of Kobarid (Fig. 1). It is a steep canyon with vertical to overhanging walls, bisecting the mountain ridge of the Vogel (Italian: Monte Voglu; $1124 \mathrm{~m}$ ) and the Mija (Italian: Monte Mia; $1237 \mathrm{~m}$ ). The recent valley entrance is approximately $200 \mathrm{~m}$ above the river course of the Nadiža River (Italian: Natisone), which is a tributary to the Torre River. The valley is oriented along-strike one of the largest and most active fault zones in the northern external Dinarides, the Predjama Fault (Buser, 1987, 2009). The remarkable morphology of the canyon (Fig. 2) and its location inevitably lead to the question of how it was formed. Previous studies suggested that melt water from the Isonzo glacier has flowed through the Pradol Valley (Tellini, 1898; Feruglio, 1929). However, the timing and mechanism of its formation have not yet been deciphered. This study aims to provide an insight into the formation process of the Pradol Valley from a geomorphological perspective. We constrain the role of major landscape forming processes, such as active tectonic deformation, glaciations, and fluvial erosion on the formation of the valley and the surrounding region and present a model that fits all available observations.

\section{Study Area}

The study area (Fig. 1) comprises the NW-SE trending Pradol Valley in the centre, the moun- tain ridge of Mija and Vogel and the surrounding valleys, forming the catchment of the Nadiža. The floor of the Pradol Valley is at an elevation of $400-450 \mathrm{~m}$, gently tilted towards the south-east, and is filled by a layer of rock debris of unknown thickness. It is 200 to $250 \mathrm{~m}$ higher than those of the other valleys that host the recent riverbed of the Nadiža. The walls of the canyon are built up of massive, bedded limestones and occasionally calcarenites that dip towards the northeast (Fig. 2). The limestone layers, ranging from upper Triassic ages at the south-eastern valley entrance to upper Cretaceous units (Buser, 1987, Carulli, 2006) in the northwest are partly folded and faulted.

Besides the Pradol Valley, the study area features other noteworthy geomorphologic elements, which help to understand the processes that shaped the landscape. The main river draining the study area, the Nadiža, attracts attention due to its unusual flow path. It emerges in the mountains north-west of the study area. At Logje, close to the entrance of the Pradol Valley, it bends about $90^{\circ}$ to the north-east. At the village of Robic the river again bends to the south at about $90^{\circ}$ and flows into the valley between Mija and Matajur (Italian: Monte Matajur). Here it cuts through a bar of solid limestone rocks of approximately $200 \mathrm{~m}$ width, $500 \mathrm{~m}$ length and $50 \mathrm{~m}$ height (see inset in Fig. 1). This is especially noteworthy as there is a wide valley to the east that connects Robič and Kobarid that is situated at the Soča River (Fig. 2). The topographic high that separates the Nadiža and the Soča River is only a few metres above the river courses and coincides with a large

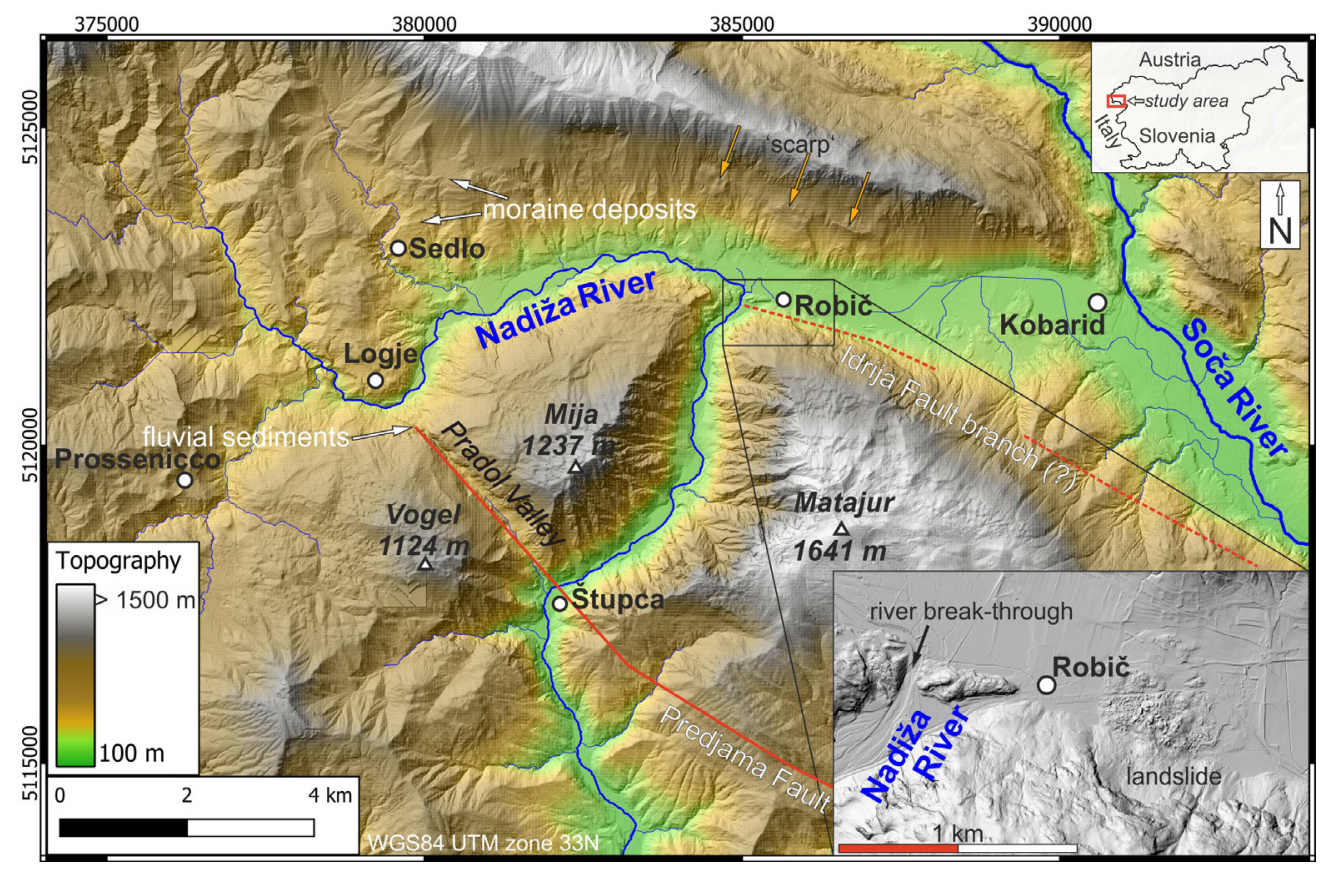

Fig. 1. Overview of the study area in north-western Slovenia, showing the location of the Pradol Valley, the flow path of the Nadiža, and the surrounding topography (coloured 1-m DEM hillshade). Orange arrows indicate the morphologic scarp formed by glacial processes. Red lines indicate known fault zones. Inset figure (bottom right) shows the elongated bedrock ridge at Robič, which is cut by the Nadiža, as well as the landslide deposits in the valley between Robič and Kobarid. 

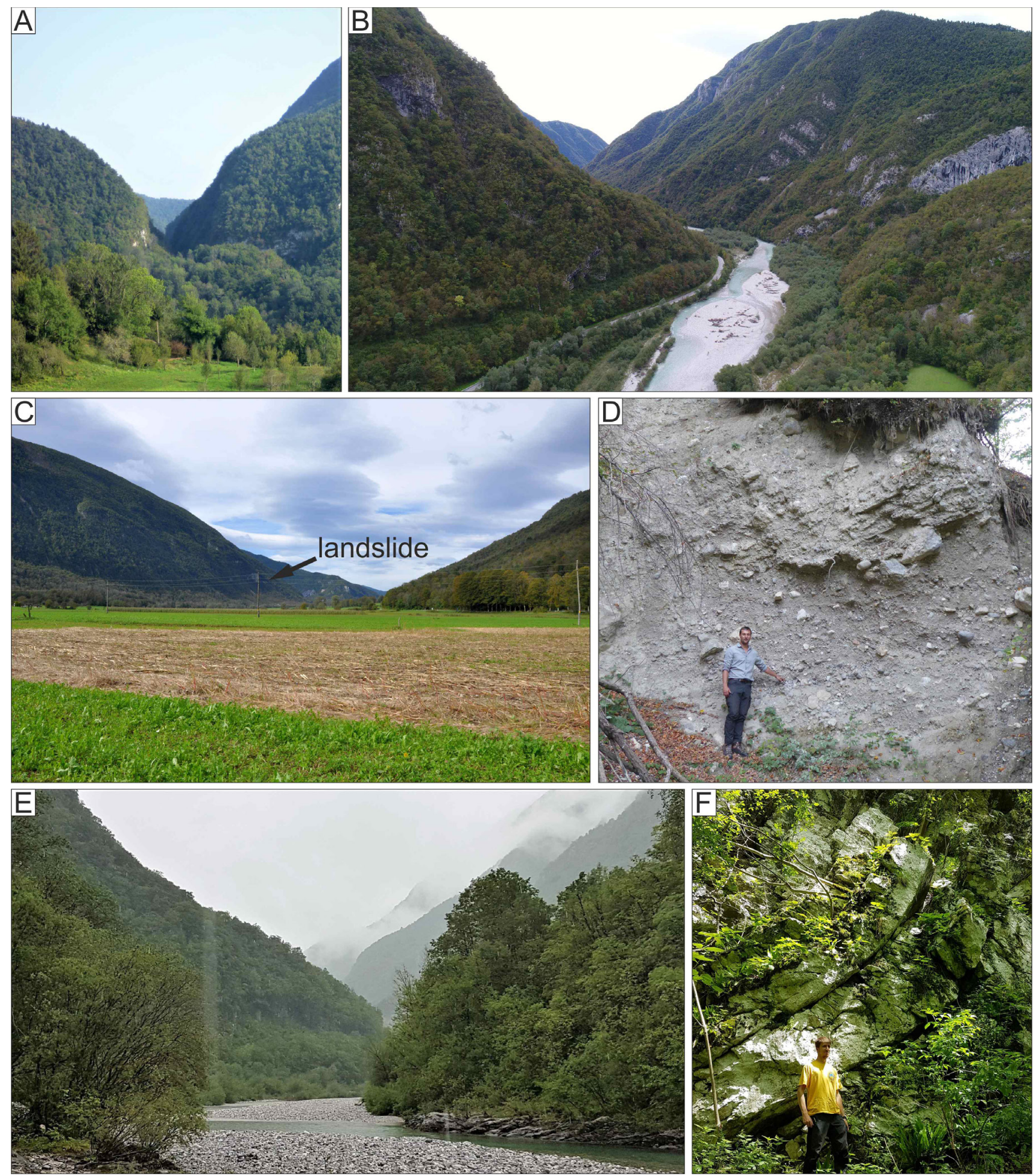

Fig. 2. A. View from Logje to the south-east across the Nadiža Valley towards the Pradol Valley. B. Valley between Matajur and Mija aerial view from Robič to the south C. U-shaped valley between Kobarid and Robič with the landslide W of Robič. View to the west. D. Outcrop of moraine deposits north of Sedlo at $500 \mathrm{~m}$ a.s.l. E. The Nadiža near the incised rock bar at Robič, view to the south. The background shows the steeply incised valley between Mija and Matajur. F. Vertical wall in the Pradol Valley exhibiting folded limestones.

landslide (Fig. 2). As the Nadiža flows around the Mija, passing both entrances of the Pradol Valley, the obvious assumption is that the Nadiža might be related to the formation of the canyon.

An important aspect of this region is its location at the north-western end of the orogen-parallel active fault system in the northern external
Dinarides. The study area features two active fault zones: the Predjama Fault, which most likely is located within the Pradol Valley (e.g. Buser, 1987, 2009, Carulli, 2006, Moulin et al., 2014), and the Idrija Fault. The exact location of the main strand of the Idrija Fault in this region is hard to pin down. One branch of the fault possi- 
bly strikes along the limestone rock bar at Robič. Both faults are neotectonically active (e.g. Moulin et al., 2014, 2016; Vrabec, 2012; Ribarič, 1979; Bavec et al., 2012) and form major topographic lineaments over distances of 100 to $120 \mathrm{~km}$.

According to Penck \& Brückner (1909), most of the study area was glaciated during the last glacial maximum (LGM). The ice, coming from the Soča Valley north of Kobarid, covered the entire valley of Kobarid, Robič, and Logje and reached up into the upper catchment of the Nadiža. The valley between Mija and Matajur was also glaciated (Penck \& Brückner, 1909). More recent studies (e.g. Bavec et al., 2004) suggest that this glacial extent is overestimated, without however proposing an alternative extent. There is general agreement that glaciers reached our study area at some point during the Pleistocene (see discussion in Ferk et al., 2015). No glaciers were present in our study area during the Little Ice Age (Colucci \& Žebre, 2016).

\section{Methods}

\section{Data and software}

The study focuses on geomorphological investigations. For overview purposes and first-order analyses, a 1-arcsecond ALOS 2 (Advanced Land Observing Satellite) digital elevation model (DEM) was used, which is provided by the Japanese Aerospace Exploration Agency (JAXA, 2019). For the Slovenian part, a 1m-DEM, which is provided by the Environmental Agency of the
Republic Slovenia (ARSO, 2020) was used. The DEM is freely available via the ARSO web service as point cloud (ascii) files. The point clouds were processed with the open-source software CloudCompare (CloudCompare, 2019). For the Italian part of the study area, a 1m-DEM of the Friuli-Venezia region is available from the Friuli-Venezia Giulia Environmental Department (RAFVG, 2019). Both high-resolution DEMs are derived via airborne laser scanning (light detection and ranging, LiDAR). The geomorphological analyses were performed using the open-source software packages TecGEMs (Shahzad et al., 2011, Andreani et al., 2013) and Topotoolbox 2 (Schwanghart \& Scherler, 2014), a Matlab-based toolbox. Further processing and visualization of the data were done with the free geographic information system QGIS (QGIS, 2020).

\section{Morphometric Indices}

For the characterisation of different topographic features, morphometric indices were calculated from the merged $1 \mathrm{~m}-\mathrm{DEM}$, using TecGEMs toolbox. The surface roughness (SR), which describes the ratio of the 'real' surface to the flat (map view) surface area (Grohmann, 2004) was computed (Fig. 3). It is calculated for each pixel of a raster DEM, referring to a 'moving window' $(2000 \times 2000 \mathrm{~m})$. An SR of 1 corresponds to entirely flat surfaces, whereas elevated values indicate rough, incised areas. The SR is presented in figure 3. Other indices indicated similar results and thus are not presented separately.

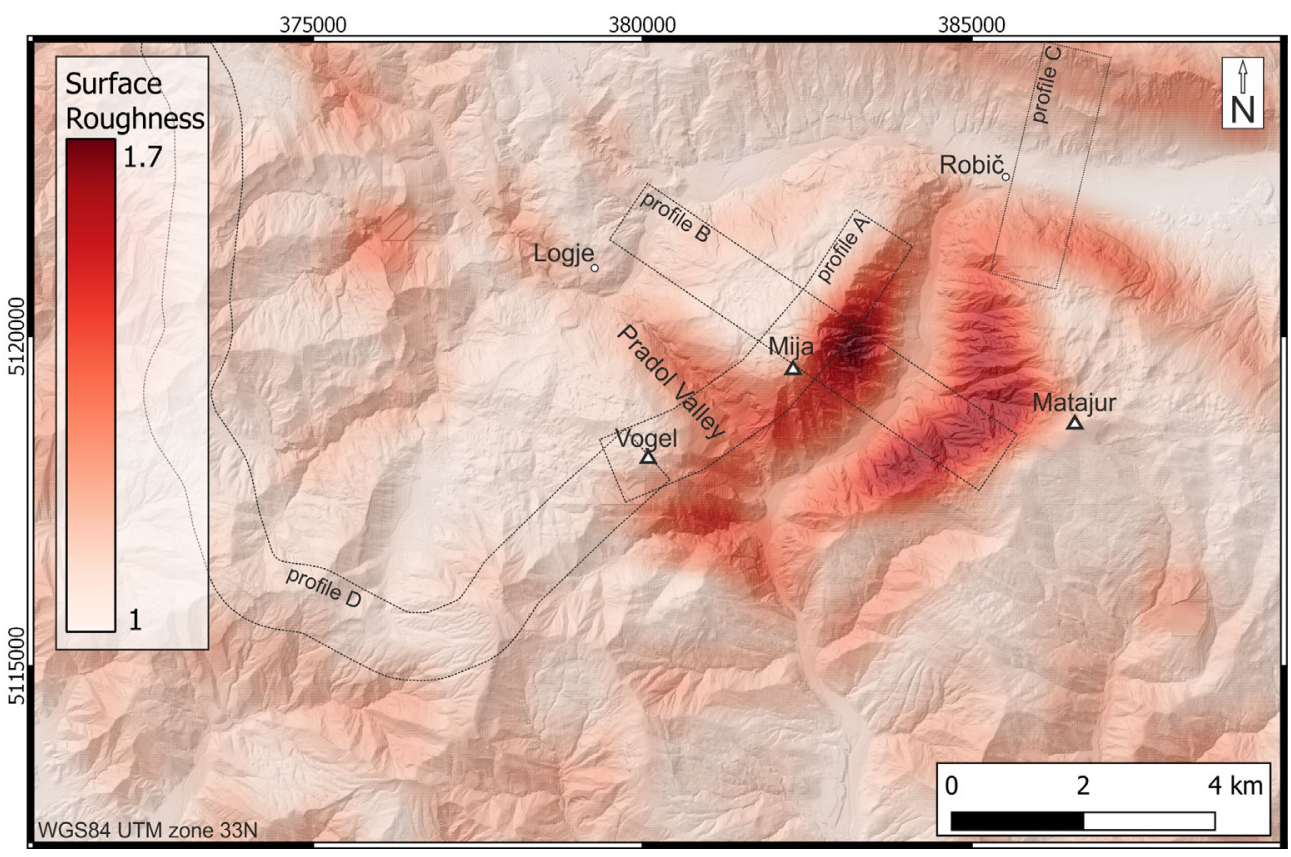

Fig. 3. Surface roughness (SR) map of the study area $\mathrm{SR}$ is notably elevated in the valley between Mija and Matajur mountains, whereas the rest of the study area exhibits relatively low values. Dashed lines indicate positions of the swath profiles A to D, depicted in Fig. 4. 


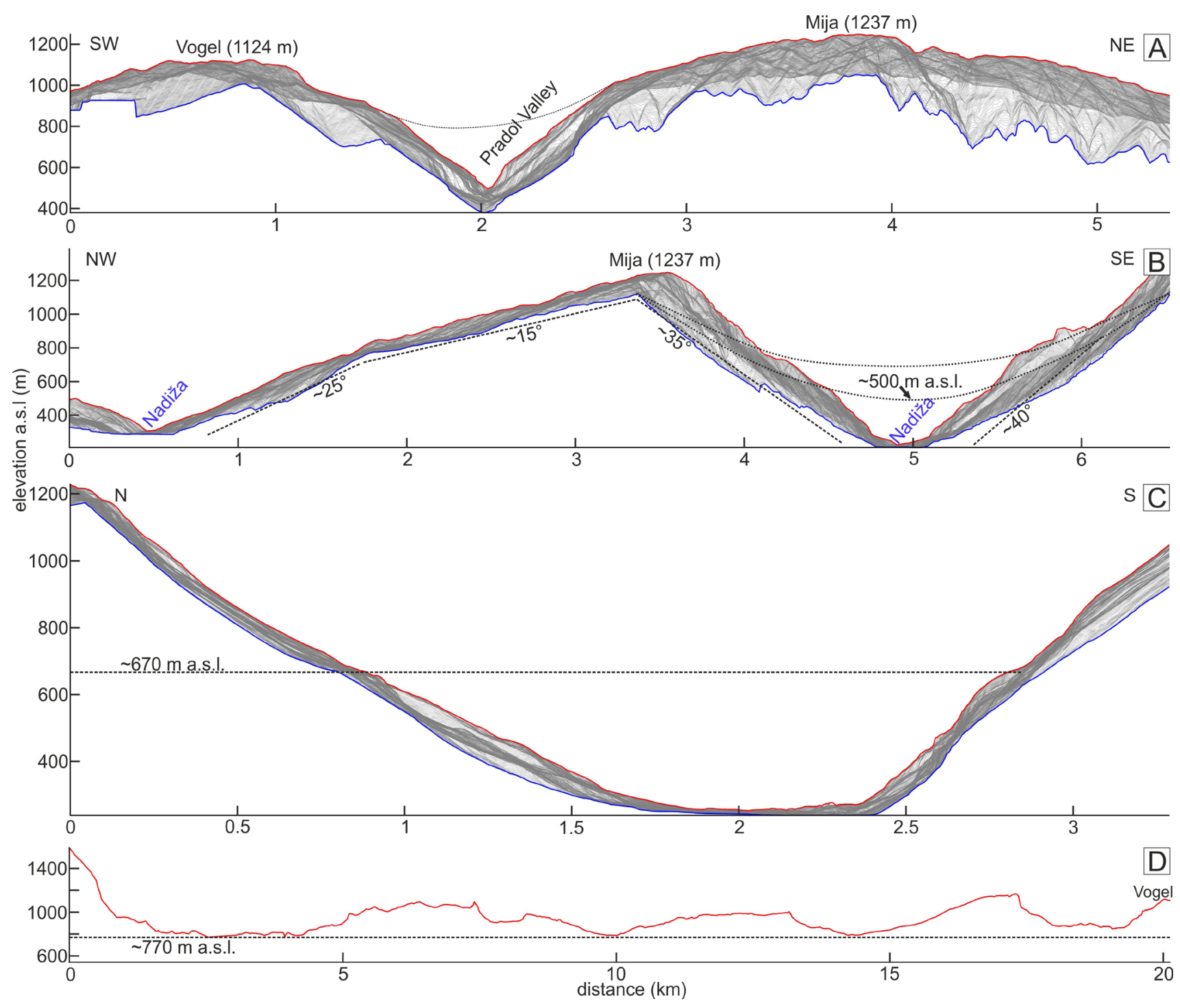

Fig. 4. Swath topographic profiles, A, B and C show maximum (red) and minimum (blue) elevation and single profiles. A. SWNE-profile along the Vogel-Mija mountain ridge, crossing the Pradol Valley perpendicularly. The lowest part of the canyon is not represented accurately due to overhanging wall. Dashed line indicates a possible pre-incision morphology. B. Profile crossing the Mija from NW to SE. The ridge is asymmetric. On the south-eastern, steeper side, the amount of incision (difference between maximum and minimum elevation) is higher. Dashed lines indicate two scenarios of pre-incision valley morphology with valley floor elevations of $\sim 500$ to $700 \mathrm{~m}$ a.s.l. C. N-S profile across the valley east of Robič, dashed line indicates elevation of the scarp. D. Curved profile (max. elevations only) along the drainage divide of the south-eastern Nadiža catchment; dashed line indicates the lowest point of the ridge at $770 \mathrm{~m}$ a.s.l. Location of all profiles is indicated in figure 3 , swath width is $1000 \mathrm{~m}$.

\section{Topographic swath profiles}

Topographic swath profiles are commonly used for detailed topographic studies of selected areas. In contrast to single profiles, swath profiles sample a large number of parallel profiles to cover an entire area instead of a single line. The individual profiles are projected to a plane parallel to the profiles and maximum, minimum and mean elevations of all profiles are condensed to a single profile (Masek et al., 1994; Andreani et al., 2014). Swath profiles contain more information than single profiles, including the position of elevated paleo-surfaces, incised river beds, and the amount of regional incision (difference between maximum and minimum elevation). In this study, topographic profiles were used for detailed investigations of the morphology of the Nadiža and Pradol Valley and to determine the elevation of the mountain chains in the study area (Fig. 4).

\section{River longitudinal profiles and analysis}

For the stream profile analysis, the high-resolution DEM was resampled to $5 \mathrm{~m}$-resolution to limit the computational demand. The profile was extracted using Topotoolbox 2 and Matlab. All streams with a minimum length of $1 \mathrm{~km}$ and a drainage area of at least $1 \mathrm{~km}^{2}$ were extracted from the DEM. Longitudinal profiles of the Nadiža and the main tributaries were derived and knickpoints were calculated using the Topotool- 

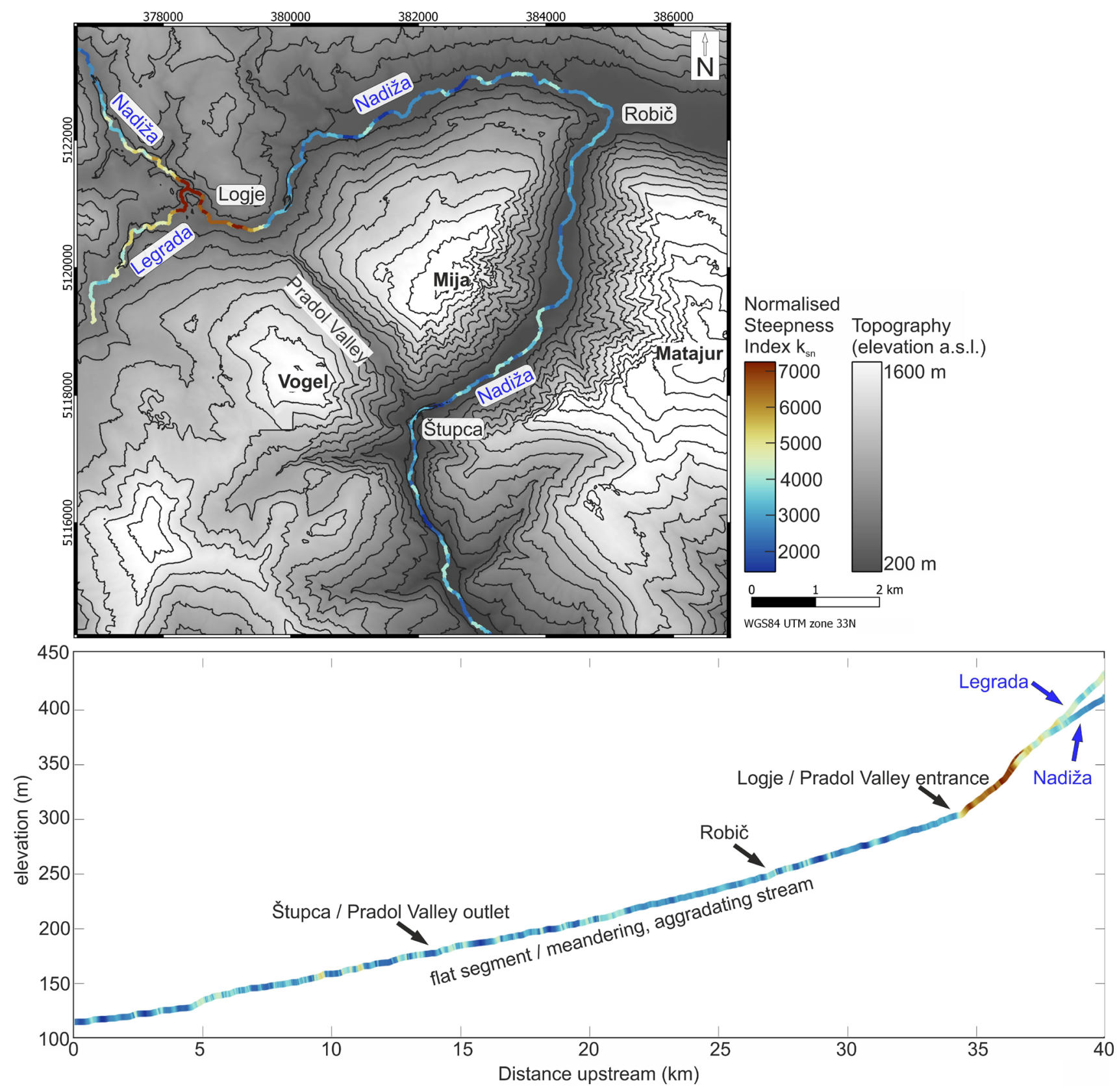

Fig. 5. Wbp: normalised steepness index $\left(\mathrm{k}_{\mathrm{sn}}\right)$ map of the Nadiža and its tributary Legrada, merging west of Logje. Background contour map based on the $1 \mathrm{~m}$ LiDAR DEM. Below: Longitudinal profile of the Nadiža and Legrada, colour-coded by normalised steepness index $\left(\mathrm{k}_{\mathrm{sn}}\right)$. The upper segment of the river is significantly steeper and exhibits high $\mathrm{k}_{\mathrm{sn}}$-values, whereas the lower segment is flat and meandering.

box 2 'knickpointfinder' function with different tolerance values between 20 and $40 \mathrm{~m}$. The 'knickpointfinder' is a geometrical approach for knickpoint detection, comparing the real profile to an ideal (steady-state) stream profile, which is commonly described by the basic stream-power law (e.g. Whipple \& Tucker, 1999; Kirby \& Whipple, 2012).

The normalised steepness index $\left(\mathrm{k}_{\mathrm{sn}}\right)$ was calculated, as described by Wobus et al., 2006. According to the stream-power law, the normalised steepness index includes the rock uplift and the coefficient of erosion (e.g. Wobus et al., 2006;
Kirby \& Whipple, 2012). Hence, elevated $\mathrm{k}_{\mathrm{sn}}$-values may be interpreted in terms of disequilibria within the stream profile. These might be caused by different factors, such as tectonic uplift or differences in channel bedrock lithology, but also by glaciations and by local or temporal changes in discharge. The $\mathrm{k}_{\mathrm{sn}}$ was calculated with a concavity index of 0.6 , which was previously determined via $\chi$-transformation (Royden et al., 2000, Perron \& Royden, 2013) of the Nadiža trunk channel. The longitudinal profile of the Nadiža and related $\mathrm{k}_{\mathrm{sn}}$ values are presented in Fig. 5. 


\section{Field work}

To complement the remote sensing studies, field work was carried out in the study area. The field work aimed at getting more precise knowledge of the morphology of the Pradol Valley, which cannot be precisely represented by airborne DEM due to the partly overhanging walls. Fluvial and glacial deposits were mapped at several points in the study area, providing important information on the glacial extent and previous river courses. The elevation of relevant features was measured at several points using combined handheld GNSS devices and barometric altimeter (Garmin eTrex and Suunto Traverse OW151). The GNSS positioning allowed a later verification with DEM and geological maps.

\section{Results}

The valley west of Kobarid has a typical glacial U-shape (Figs. 2C, 3, 4C). At an elevation between 670 and $730 \mathrm{~m}$, a morphological scarp can be observed both in the topographic swath profile (Fig. 4C) and in the high resolution DEM (see orange arrows at the northern mountain ridge in Fig. 1). North of the village of Logje (close to the village Sedlo), we investigated several outcrops at an elevation between 500 and $700 \mathrm{~m}$ that exhibit poorly sorted sediments. The grain size varies between clay and boulders with 2 metres diameter. The sediments are unconsolidated and seem to have a weak layering with grains made of carbonates. The outcrops resemble typical moraine deposits. We found the highest outcrops at $\sim 680 \mathrm{~m}$ a.s.l., which is close to the elevation of the morphologic scarp further to the east of the valley.

East of Robič, a landslide of unknown age with a head scarp on the southern side of the valley is visible both in the field (Fig. 2C) and in the DEM (Fig. 1). Although the landslide deposits are clearly visible on the valley floor, their influence on the overall valley morphology is low.

The valley south of Robič, between Mija and Matajur, has a different morphology. As seen in the topographic swath profile (Fig. 4B), the valley has a relatively steep V-shape with hillslope angles of $35^{\circ}$ to $45^{\circ}$ on both sides (see also photo in Figs. 2B, E). The lowest part of the valley is even steeper than the upper portion of the adjacent hills. The scarp, which is likely related to marginal moraines, cannot be observed in most parts of this valley. Compared to the surrounding region the valley has an increased surface roughness (Fig. 3) and incision (Fig. 4B).
While the Nadiža Valley is comparably wide and flat north of the Mija, it is steeply incised on the south-eastern side of the mountain. This leads to an overall asymmetric shape of the mountain ridge (Fig. 3B). The surface of the ridge is inclined $\sim 15^{\circ}$ on the north-western side and gets slightly steeper in the lowest section close to the river channel. The south-eastern flank of the valley is inclined $\sim 35^{\circ}$, similar to the counterpart of the Matajur ( 40 $0^{\circ}$ Fig. 4B). If the Mija was symmetric, with an inclination between 15 and $25^{\circ}$ on both sides, the south-eastern valley would have an elevation of at least $500 \mathrm{~m}$ (dashed curve in Fig. 4C).

The Nadiža stream (Figs. 1, 5) is steep in the upper segment, where it features elevated $\mathrm{k}_{\mathrm{sn}}$-values. The steep segment reaches downstream approximately to the location of Logje, where it enters the wide and flat valley. Here the stream character changes from steep and incising to a flat, meandering river with comparably low $\mathrm{k}_{\mathrm{sn}}$-values. Even in the strongly incised valley downstream of Robič, the recent river has a flat profile and aggradates river terraces.

The Pradol Valley itself has a remarkable morphology. The recent valley floor is at an elevation between 400 and $450 \mathrm{~m}$ a.s.l. and is covered by rock debris. The debris consists of angular limestone blocks from the adjacent walls and forms a layer covering the entire valley floor with irregular shape and thickness. The walls of the canyon, especially in the lower portion, are very steep (Fig. $2 \mathrm{~F}$ ), partly even overhanging. Due to the thick rock debris cover and dense vegetation, no remnants of fluvial sediments could be found within the valley. However, at the north-western valley entrance deposits of rounded, well-sorted carbonate pebbles, most probably fluvial sediments, crop out at elevations up to $400 \mathrm{~m}$ a.s.l. (see Fig. 1)

\section{Interpretation}

Several geologically viable explanations for the formation of the Pradol Valley appear plausible. However, most scenarios can be excluded due to at least one of the observed facts. Several studies of dry valleys around the world have shown that tectonic uplift may lead to the abandonment of river beds, reorientation of streams, and finally the formation of wind gaps (e.g., New Zealand: Tomkin \& Braun, 1999; California: Keller et al., 1998; Greece: Goldsworthy \& Jackson, 2001). Moulin et al. (2016) report in detail on the Čepovan Canyon, which is a large dry valley SE of our study area on the Trnovski Gozd Plateau. The canyon is cut by the Predjama Fault and its 


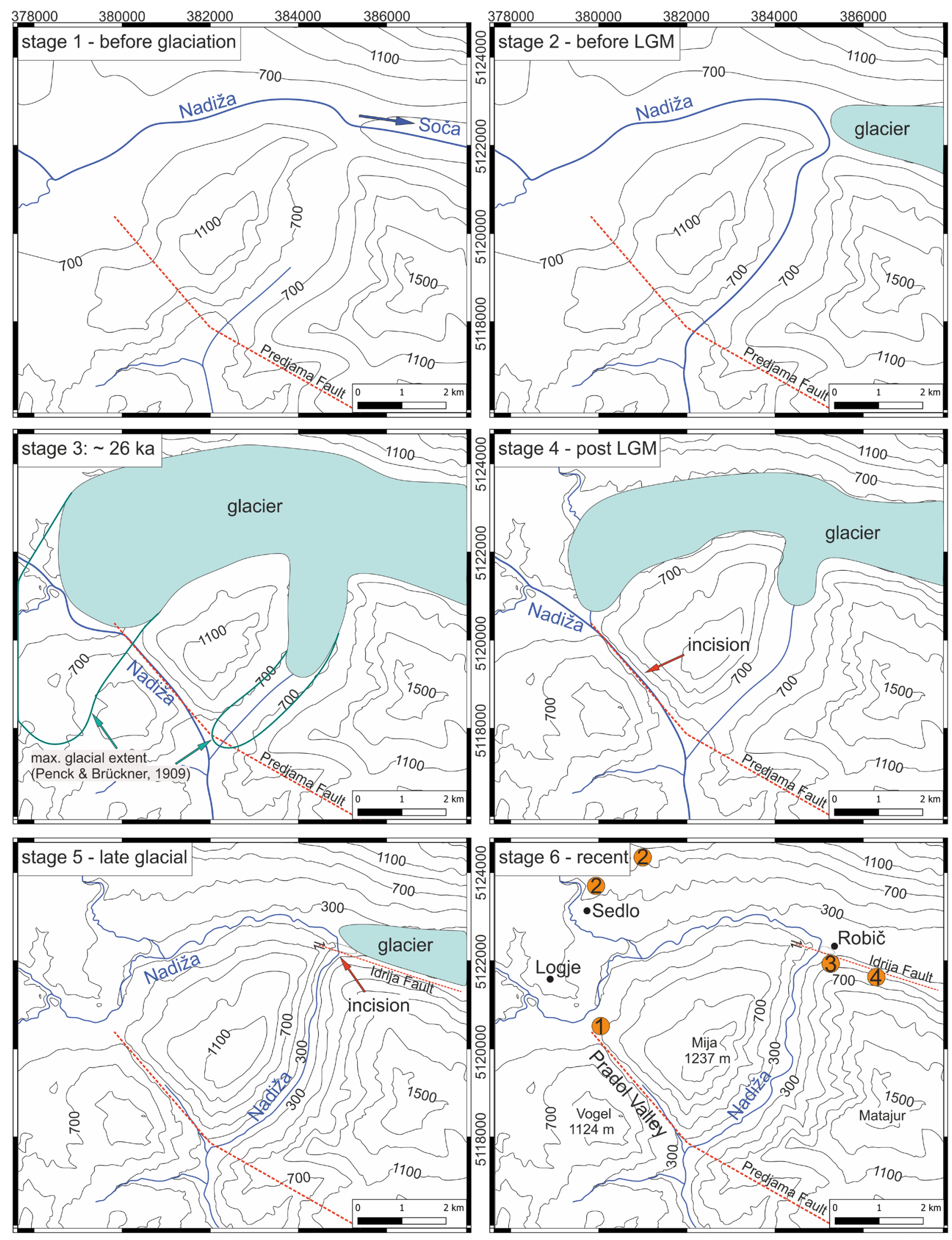

Fig. 6. Interpreted scenario of the formation of the Pradol Valley and the surrounding topography in six stages. Stage 6 features the recent topography (smoothed contour plot extracted from the $1 \mathrm{~m} \mathrm{DEM}$ ) and the location of the most important findings leading to the interpretation: 1) fluvial sediments at the north-western entrance of the Pradol Valley at $400 \mathrm{~m}$ a.s.1. 2) findings of glacial deposits (moraines) at 500 to $700 \mathrm{~m}$ a.s.l. 3) incised limestone rock at Robič 4) landslide in the Kobaridvalley. Stage 1 to 5 are constructed by stepwise modification of the recent topography based on the explained interpretations. (map projection: WGS 84 UTM zone $33 \mathrm{~N}$, north up). 
slightly folded floor is also situated hundreds of metres above the surrounding valleys. This canyon is thought to have formed in the last $2.5 \mathrm{Ma}$ and to have recorded several hundreds of metres of tectonic uplift and shortening (Moulin et al., 2016). In the case of the Pradol Valley, however, tectonic forcing can be excluded as the main driving force of its formation for two reasons:

First, the study area does not exhibit appropriately oriented thrust faults to uplift the Pradol Valley. The known active fault zones are predominantly strike-slip faults with minor uplift components only (Placer et al., 2010; Vrabec, 2012; Moulin et al., 2016). However, we cannot rule out the existence of blind thrust faults that do not reach the surface.

Second, the overall slip rate at the orogen-parallel fault system, induced by the collision of the Adriatic microplate and Eurasia, is too low to reach such amounts of uplift. Although the elevation of the mountain ridge before the incision of the Pradol Valley is unknown, the recent elevation of the two peaks (1124 and $1237 \mathrm{~m}$ ) and the morphology of the ridge (see Fig. 4A) suggest that it was at least $700 \mathrm{~m}$ a.s.l., resulting in a necessary uplift of at least $300 \mathrm{~m}$. The walls of the canyon are very steep and weakly eroded, which indicates that the formation is relatively young, probably post-glacial. This would result in unrealistically high uplift rates.

The irregular flow path of the Nadiža that cuts the bedrock ridge at Robič and which passes both entrances of the Pradol Valley as well as the remarkable shape of the valley south of Robic leads us to assume that the formation of all these morphologic features is related to the same process that incised the canyon. Here we propose a formation scenario, which takes into account all above-mentioned findings and explains the described morphologic features (Fig. 6).

The valley between Robič and Kobarid is wide and flat. The size and the morphology of the valley indicate that it was originally carved by a river and later further eroded by a glacier, leading to the typical U-shaped profile. It was most likely the original flow path of the Nadiža, before the glaciation and the change of the drainage pattern (stage 1 in Fig. 6). Hence, at this stage the Nadiža probably drained into the Soča instead of occupying the N-S-trending valley between Mija and Matajur. The incision of this valley was probably triggered by blocking of the Nadiža by glaciers coming from the north during a glacial advance (stage 2 in Fig. 6). According to the reconstruction of the valley with a symmetrical shape of the
Mija ridge (Fig. 4B), the valley floor at this time was at an elevation of at least $500 \mathrm{~m}$, about 300 $\mathrm{m}$ higher than today. This estimated elevation is plausible, considering that no major fluvial or glacial erosion took place before that stage. In an alternative model the Nadiža drained towards the south between Mija and Matajur already before the last glacial maximum. In this case the wide valley between Robič and Kobarid was dominantly shaped by a glacier. This alternative model does still comply with the stages $2-6$ (Fig. 6).

The maximum glacial extent during the LGM is still debated (and further investigations are hindered by poor outcrop conditions and low chances of moraine preservation), but the Pleistocene glaciers advanced far enough to fill the entire valley, covering the recent locations of Robič and Logje (Bavec \& Verbič, 2004a; Bavec et al., 2004b; Ferk et al., 2015; Penck \& Brückner, 1909). The difference between the recent valley floor of the U-shaped valley (Fig. 4C) and the remnants of marginal moraines indicates an ice cover of at least 400 to $500 \mathrm{~m}$. This blocked the outlet of the Nadiža (stage 3 in Fig. 6). Our interpretation is supported by the findings of lacustrine sediments near the village of Prossenicco (Fig. 1), as described by Feruglio (1929), who also proposed the idea that this glacial lake might have drained through the Pradol Valley. The glacier also advanced into the valley south of Robič, resulting in erosion of that valley.

The ice caps of the Alps reached their maximum extent at about $26 \mathrm{ka}$ and lasted until approximately $20-19 \mathrm{ka} \mathrm{BP}$ (Clark et al., 2009). During this time (including an unknown amount of time before and after the maximum glacial extent), the Nadiža and the melt water from the glacier did not have an outlet. The lowest part of the mountain ridge south-west of Logje and the Vogel is at an elevation of $770 \mathrm{~m}$ (recent elevation, fig. 4D), so this could not have served as an outlet for the stream either. The only possible explanation for this is the formation of the Pradol Valley, which probably served as an outlet only for this limited time span (stage 3 to 4 in Fig. 6). Therefore, two main requirements must have been fulfilled: First, the mountain ridge must have been lower than the estimated maximum elevation of the glacier, otherwise it would be unlikely that the water drained through the mountain. The highest marginal moraine deposits are located slightly above $700 \mathrm{~m}$ a.s.l. Accordingly, the ridge between both peaks (Mija and Vogel) must have been indented to an elevation of ca. 700 (max. 770) metres 
before the LGM, which is plausible, as shown in figure 4A. Secondly, the bedrock probably had been weakened before the glaciation; otherwise the remarkably fast incision would be unlikely. The extraordinarily steep incised canyon with vertical to overhanging walls indicates that the incision rate was much faster than in common bedrock rivers. Both presumptions can be explained by the presence of the Predjama Fault, which is probably running through the Pradol Valley. The fault would form a natural weakness zone in the bedrock and hence become the preferred location for the river to start incising. Additionally, similar to the fault traces of the other main active faults, which can be observed in the modern topography (e.g., Cunningham et al., 2007; Moulin et al., 2014), the fault scarp formed an indentation in the mountain ridge. Although this assumption cannot be conclusively proven, it is the only valid explanation to date and is strengthened by the described findings.

The incision of the Pradol Valley lasted until the glacier retreated far enough for the Nadiža to again readjust its course and resume draining along its former flow path before its incision of the Pradol Valley (stage 5), thus abandoning it. At Kobarid, the glaciation lasted longer than in the western part of the valley, due to the glaciers coming from the Bovec Basin and the Soča Valley north of Kobarid. Accordingly, the outlet towards the Soča was still blocked, forcing the river to cut through the bedrock ridge at Robič and drain into the southern valley between Mija and Matajur (stage 5). This was enhanced by an increased discharge, due to the melting glaciers and the previous glacial erosion of the valley. This period of incision of the valley led to its steep morphology, the high surface roughness, and the asymmetry of the Mija ridge. In the alternative model that has the Nadiža draining this valley even before the LGM, the situation would be the same and intensified erosion would still lead to a deep incision. At this point it is worth noting that the limestone layers of Mija also dip towards the NW (Buser, 1987). However, these are much steeper $\left(33-55^{\circ}\right)$ than the surface $\left(15-25^{\circ}\right)$, so the morphology cannot be solely interpreted as a result of geologic properties. The landslide near Robič could also be interpreted as a possible cause of a blocked river, but it probably would be too small to withstand the combined discharge of a melting glacier and the Nadiža. Furthermore, the lack of an incised river bed indicates that the Nadiža did not take this path since the LGM.
After the glacial period the incision ceased and the Nadiža changed to a less steep, meandering river (at least in the lower parts), finally leading to the recent morphology (stage 6). We interpret the steep river segment in the upstream portion of the Nadiža (Fig. 5) as the remnant of higher discharge and stronger incision, which is now slowly migrating upstream. This steep segment is not affected by lithologic contrasts (Buser, 1987; Carulli, 2006) or other environmental effects. The lower part of the stream has already re-equilibrated since the end of the last glacial period.

The last stage (Fig. 6, stage 6) features the recent topography and all findings which led to the interpretation of this scenario: the fluvial sediments at the Pradol Valley entrance (1), the glacial deposits from the LGM (2), the position of the incised limestone rock at Robič (3) and the landslide (4).

\section{Discussion}

The previously explained scenario of the formation of the Pradol Valley is based on several assumptions. The main assumption necessary to explain the formation of the canyon is the indentation of the mountain ridge before the main episode of fluvial incision. To form the outlet of the blocked valley, the ridge must not have been higher than 700 to $800 \mathrm{~m}$ at its lowest point. This assumption is supported by the presence of the Predjama Fault zone. Further uncertainties of the interpretation are induced due to unknown timing of the expected events, especially stages 1 to 3 (Fig. 6).

Despite some uncertainties, several interpretations can be verified. First, the Nadiža is the only stream in the region which has enough discharge to force major erosion processes. This, along with the flow path passing both Pradol Valley entrances and the fluvial sediments, justifies the interpretation that the Nadiža is responsible for the incision of the valley. Secondly, although the maximum glacial extent is still debated, the blocking of the Nadiža during the Pleistocene is proven by the finding of marginal moraine deposits at elevations up to $700 \mathrm{~m}$. Therefore, if this moraine is indeed from the LGM, the Pradol Valley forms the only possible outlet of the Nadiža and the glacier melt water for the time span between at least $26 \mathrm{ka}$ and $19 \mathrm{ka} \mathrm{BP}$.

The sub-vertical section of the canyon is approximately $150 \mathrm{~m}$ high (Fig. 3A). Above this part, the canyon profile has a steep V-shape, indicating that the original ridge was at least $700 \mathrm{~m}$ high. This results in an incision of at least 
300 metres during the maximum glacial extend $(\sim 7 \mathrm{ka})$ plus an unknown amount of time before and after the LGM. Assuming a time span of 7 to $15 \mathrm{ka}$, an incision rate of 20 to $43 \mathrm{~mm} / \mathrm{a}$ is derived. Incision rates in this order typically only occur within actively uplifting mountain belts or at larger rivers (e.g. Seong et al., 2008, Sanders et al., 2014 and citations therein). Studies of gorge formation in the French Alps showed less intense incision rates (Valla et al., 2010; up to $15 \mathrm{~mm} / \mathrm{a}$ ). None of the mentioned studies resembles the conditions given at the Pradol Valley, regarding bedrock erodibility, river discharge and sediment load, making a direct comparison pointless. However, these studies show that our calculated incision rates fall into a range that could possibly occur in a natural stream. The pre-existing weakness zone along the Predjama Fault combined with elevated discharge due to melting of the Soča Glacier likely accelerated the incision of the Pradol Valley.

Altogether, the scenario we propose explains all noteworthy morphologic and geologic findings of the study area, including the location of active fault zones, the occurrence of fluvial and glacial deposits, the rather uncommon recent river flow paths, and the strongly incised valleys.

Although our model can explain all the observations with a post-LGM formation of the Pradol Valley, we cannot rule out the possibility that the Pradol resulted from multiple incision phases during the last few glacial cycles, or that it formed in an earlier glacial advance in the Pleistocene that exceeded the one during the LGM. One argument for multiple cycles of incision is the extraordinary depth of the canyon and the very high incision rates resulting if it were all formed post-LGM. On the other hand, the almost vertical canyon walls indicate that no significant post-incision modification by mass movements took place, which would be expected if the canyon had undergone multiple ice advances or if it was significantly older than the LGM. We note that this question could perhaps be answered by systematic exposure dating along a vertical profile from the Pradol Valley floor up to the top of the canyon.

\section{Conclusion}

We conclude that the Pradol Valley must have had a major episode of incision during the LGM, lasting ca. 7-15 kyr due to the blocking of the Nadiža channel by glaciers coming from NE. The canyon probably incised at least $300 \mathrm{~m}$, resulting in incision rates of 2 to $4 \mathrm{~cm} / \mathrm{a}$. The extreme in- cision rates appear plausible, as the canyon has very steep, partly overhanging walls, documenting fast erosion. Additionally, cataclastic abrasive wear of the bedrock caused by faulting along the Predjama Fault located along-strike the canyon likely contributed to this process. It remains unclear whether the entire canyon was carved by this one event, or if the formation started during earlier glacials.

Our study demonstrates that a complex interplay of glacial, fluvial and tectonic processes is the driving force of landscape evolution in this area. Accordingly, studies in related fields, such as tectonic geomorphology, should be treated carefully, especially in areas affected by former glacial processes.

\section{Acknowledgements}

This research was funded by DFG grant number "GR 4371/1-1". This project is part of the "SPP2017Mountain Building Processes in 4D". We thank Eilyn Becher and Julian Welte for their help in the field. Furthermore we thank the two anonymous reviewers whose comments and suggestions improved the quality of the manuscript.

\section{References}

Andreani, L., Stanek, K. P., Gloaguen, R., Krentz, O. \& Domínguez-González, L. 2014: DEMbased analysis of interactions between tectonics and landscapes in the Ore Mountains and Eger Rift (East Germany and NW Czech Republic). Remote Sensing, 6/9: 7971-8001. https://doi.org/10.3390/rs6097971

ARSO - Environmental Agency of the Republic Slovenia 2019: 1-meter LiDAR DEM Slovenia, open-access download http://gis.arso.gov.si/ (accessed 5/2019)

Bavec, M., Tulaczyk, S. M., Mahan, S. A. \& Stock, G. M. 2004: Late Quaternary glaciation of the Upper Soča River Region (Southern Julian Alps, NW Slovenia). Sedimentary geology, 165/3-4: 265-283. https://doi.org/10.1016/j. sedgeo.2003.11.011

Bavec, M. \& Verbič, T. 2004: The extent of Quaternary glaciations in Slovenia. Quaternary Glaciations-Extent and Chronology, Part. I: Europe. Developments in Quaternary Science, 2: 385-388. https://doi.org/10.1016/ B978-0-444-53447-7.00029-5

Bavec, M., Car, M., Stopar, R., Jamšek, P. \& Gosar, A. 2012: Geophysical evidence of recent activity of the Idrija fault, Kanomlja, NW Slovenia. Materials and geoenvironment, 59: 247-256. 
Buser, S. 1987: Osnovna geološka karta, list Tolmin in Videm (Udine) 1: 100.000. Zvezni geološki zavod, Beograd.

Buser, S. 2009: Geološka karta Slovenije 1: 250.000. Geološki zavod Slovenije, Ljubljana.

Carulli, G.B. 2006: Carta Geologica del Friuli Venezia Giulia 1: 150.000. Regione Autonoma Friuli Venezia Giulia, Direzione Regionale Ambiente e Lavori Pubblici, Servizio Geologico Regionale, SELCA Firenze.

Clark, P. U., Dyke, A. S., Shakun, J. D., Carlson, A. E., Clark, J., Wohlfarth, B., Mitrovica, J. X., Hostetler, S. W. \& McCabe, A. M. 2009: The last glacial maximum. Science, 325/5941: 710714. https://doi.org/10.1126/science.1172873

CloudCompare (version 2.11 alpha) - GPL software (open-source) 2019: Retrieved from http://www.cloudcompare.org (accessed 3/2019)

Colucci, R. R. \& Žebre, M. 2016: Late Holocene evolution of glaciers in the southeastern Alps. Journal of Maps, 12/1: 289-299. https://doi.or g/10.1080/17445647.2016.1203216

Cunningham, D., Gosar, A., Kastelic, V., Grebby, S. \& Tansey, K. 2007: Multi-disciplinary investigations of active faults in the Julian Alps, Slovenia. Acta Geodynamica et Geomaterialia, 4/1: 77-85.

Ferk, M., Gabrovec, M., Komac, B., Zorn, M. \& Stepišnik, U. 2017: Pleistocene glaciation in Mediterranean Slovenia. Geological Society, London, Special Publications, 433/1: 179-191.

Feruglio, E. 1929: Note illustrative della carta geologica delle Tre Venezie: foglio Udine. Società coop. tip. [In Italian]

Goldsworthy, M. \& Jackson, J. 2001: Migration of activity within normal fault systems: examples from the Quaternary of mainland Greece. Journal of Structural Geology, 23/23: 489-506.

Grohmann, C. H. 2004: Morphometric analysis in geographic information systems: applications of free software GRASS and R. Computers \& Geosciences, 30/9-10: 1055-1067.

JAXA - Japanese Aerospace Exploration Agency 2019: ALOS 1-arc-second digital elevation model, free download (free account needed): https://www.eorc.jaxa.jp/ALOS/en (accessed 5/2019)

Keller, E. A., Zepeda, R. L., Rockwell, T. K., Ku, T. L. \& Dinklage, W. S. 1998: Active tectonics at Wheeler ridge, southern San Joaquin valley, California. Geological Society of America Bulletin, 110/3: 298-310.
Kirby, E. \& Whipple, K. X. 2012: Expression of active tectonics in erosional landscapes. Journal of Structural Geology, 44: 54-75. https://doi.org/10.1016/j.jsg.2012.07.009

Masek, J. G., Isacks, B. L., Gubbels, T. L. \& Fielding, E. J. 1994: Erosion and tectonics at the margins of continental plateaus. Journal of Geophysical Research: Solid Earth, 99/B7: 13941-13956. https://doi. org/10.1029/94JB00461

Moulin, A., Benedetti, L., Gosar, A., Jamšek Rupnik, P., Rizza, M., Bourlès, D. \& Ritz, J. F. 2014: Determining the present-day kinematics of the Idrija fault (Slovenia) from airborne LiDAR topography. Tectonophysics, 628: 188205. https://doi.org/10.1016/j.tecto.2014.04.043 Moulin, A., Benedetti, L., Rizza, M., Jamšek Rupnik, P., Gosar, A., Bourles, D., Keddadouche, K., Aumaître, G., Arnold, M., Guillou, V. \& Ritz, J. F. 2016: The Dinaric fault system: Large-scale structure, rates of slip, and Plio-Pleistocene evolution of the transpressive northeastern boundary of the Adria microplate. Tectonics, 35/10: 22582292. https://doi.org/10.1002/2016TC004188

Penck, A. \& Brückner, E. 1909: Die Alpen im Eiszeitalter. Vol. 3. CH Tauchnitz.

Perron, J. T. \& Royden, L. 2013: An integral approach to bedrock river profile analysis. Earth Surface Processes and Landforms, 38/6: 570576. https://doi.org/10.1002/esp.3302

Placer, L., Vrabec, M. \& Celarc, B. 2010: The bases for understanding of the NW Dinarides and Istria Peninsula tectonics. Geologija, 53/1: 5586. https://doi.org/10.5474/geologija.2010.005

QGIS (version 3.4.6 Madeira) QGIS Development Team 2019. QGIS Geographic Information System. Open Source Geospatial Foundation Project. http://qgis.osgeo.org

RAFVG - Regione Autonoma Friuli-Venezia Giulia 2019: - 1-meter LiDAR DEM FriuliVenezia - provided by the Friuli-Venezia Giulia Environmental Department, http:// www.regione-fvg.it/rafvg/cms/RAFVG/ambiente-territorio/-conoscere-ambiente-territorio/ (accessed 6/2018)

Ribarič, V. 1979: The Idrija earthquake of March 26, 1511-a reconstruction of some seismological parameters. Tectonophysics, 53/3-4: 315-324. https://doi.org/10.1016/0040-1951(79)90076-3

Royden, L. H., Clark, M. K. \& Whipple, K. X. 2000: Evolution of river elevation profiles by bedrock incision: Analytical solutions for transient river profiles related to changing uplift and precipitation rates. Eos Trans. AGU, 81/48. 
Sanders, D., Wischounig, L., Gruber, A. \& Ostermann, M. 2014: Inner gorge-slot canyon system produced by repeated stream incision (eastern Alps): significance for development of bedrock canyons. Geomorphology, 214: $\quad 465-484$. https://doi.org/10.1016/j. geomorph.2014.03.007

Schwanghart, W. \& Scherler, D. 2014: TopoToolbox 2-MATLAB-based software for topographic analysis and modeling in Earth surface sciences. Earth Surface Dynamics, 2/1: 1-7. https://doi.org/10.5194/ESURF-2-1-2014

Seong, Y. B., Owen, L. A., Bishop, M. P., Bush, A., Clendon, P., Copland, L., Finkel, R.C., Kamp, U. \& Shroder Jr, J. F. 2008: Rates of fluvial bedrock incision within an actively uplifting orogen: Central Karakoram Mountains, northern Pakistan. Geomorphology, 97/3-4: 274-286. https://doi.org/10.1016/j. geomorph.2007.08.011

Shahzad, F. \& Gloaguen, R. 2011: TecDEM: A MATLAB based toolbox for tectonic geomorphology, Part 1: Drainage network preprocessing and stream profile analysis. Computers \& Geosciences, 37/2: 250-260. https://doi.org/10.1016/j.cageo.2010.06.008

Tellini, A. 1898: Intorno alle tracce abbandonate da un ramo dell'antico ghiacciaio del Fiume Isonzo nell'alta valle del Fiume Natisone e sull'antica connessione tra il corso superiore dei due Fiumi. Tipografia Seitz, Udine. [In Italian]
Tomkin, J. H. \& Braun, J. 1999: Simple models of drainage reorganisation on a tectonically active ridge system. New Zealand Journal of Geology and Geophysics, 42/1: 1-10.

Valla, P. G., Van Der Beek, P. A. \& Lague, D. 2010: Fluvial incision into bedrock: Insights from morphometric analysis and numerical modeling of gorges incising glacial hanging valleys (Western Alps, France). Journal of Geophysical Research: Earth Surface, 11/F2. https://doi.org/10.1029/2008JF001210

Vrabec, M. 2012: Evidence of Quaternary faulting in the Idrija fault zone, Učja canyon, NW Slovenia Znaki kvartarne tektonske aktivnosti v coni Idrijskega preloma pri Učji. RMZ-Materials and Geoenvironment, 59/23: 285-298.

Whipple, K. X. \& Tucker, G. E. 1999: Dynamics of the stream-power river incision model: Implications for height limits of mountain ranges, landscape response timescales, and research needs. Journal of Geophysical Research: Solid Earth, 104/B8: 17661-17674. https://doi.org/10.1029/1999JB900120

Wobus, C., Whipple, K. X., Kirby, E., Snyder, N., Johnson, J., Spyropolou, K., Crosby, B. \& Sheehan, D. 2006: Tectonics from topography: Procedures, promise, and pitfalls. Special Papers Geological Society of America, 398: 55. https://doi.org/10.1130/2006.2398(04) 